\title{
筑波大学水戸地域医療教育センター・水戸協同病院 カンファレンス
}

\section{筋力低下を来した 23 歳男性}

症例提示者 : 徳田安春（筑波大学水戸地域医療教育センター・水戸協同病院） 出席：水戸協同病院研修医

本日の Case Conference は筋力低下（weakness）の症例を診ていきます。筋 力低下の患者さんの鑑別診断においてはまず，倦怠感からくる主観的な脱力感で 筋力低下が実際には無いという状況を除外します。筋力低下が明らかにある場合 には, 神経解剖学的な部位診断の中でどのような病態が起こっているかを考えな がら鑑別診断を行います．次に病歴情報を集めて，頻度の高いもの，そして見逃 してはならない疾患をリストアップしていきます。その後鑑別していくうえで重 要な検査計画を立てていきます。どのような検査を優先的に行うのかなどの検査 の選択には, その検査の利用可能性・侵襲性・コストも加味して検査をオーダー します，得られた検査結果を踏まえて最終的に鑑別診断を絞ります．確定診断を 行うために特別な検査, たとえば病理組織検査, あるいは免疫学的, 血清学的検 査の適応があれば最終検査 (diagnostic test) として行います (図 1) (徳田安春).

\section{症例}

\section{3 歳男性}

\section{主訴： 5 日前からの下肢筋力低下}

この方は学生です。まずは, この主訴から考えられ る疾患を考えていきたいと思います．今回は筋力低下 ですので神経解剖 (neuroanatomy) についても復習 しながら進めていきます. 筋力低下の鑑別診断の場 合,まず重要な前提があります。
Check Point : 筋力低下の前提として本当に筋力が 低下しているのか

それとも倦点感による自覚症状として脱力感がある のか.

Check Point : 自覚症状としての「脱力感」では筋 カが低下していないことがある

倦急感が主体であって実際は筋力低下がないという 病態はありますか？

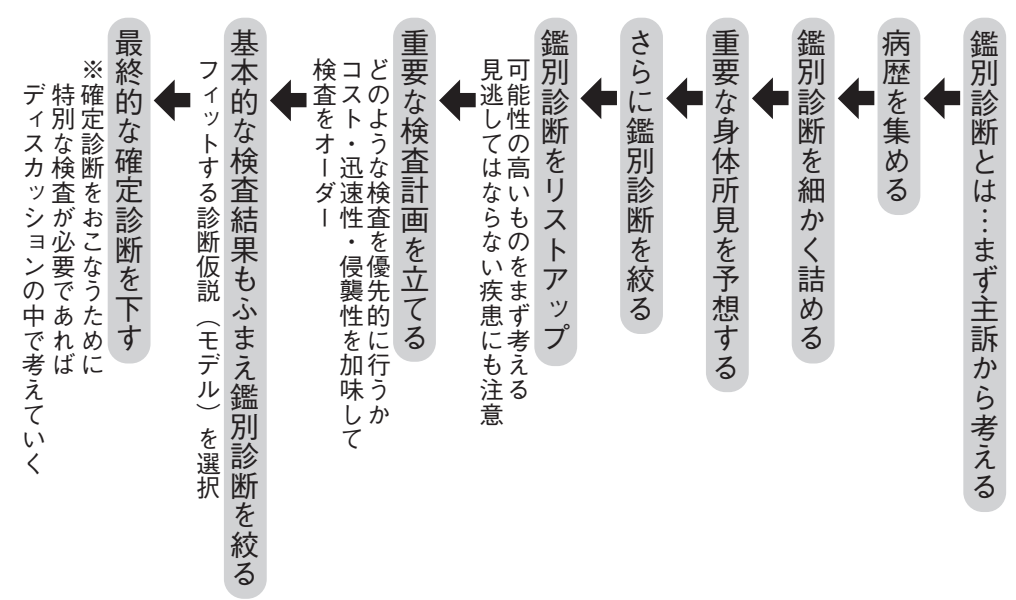

図 1 ケースカンファレンスの流れ 
研修医 A：感染症ですか？

そうですね. たとえばウイルス感染症, 敗血症, 貧 血, 臟器不全などありますね. なかには他覚的にも筋 力が低下しているものもあります。本症例では自覚 的・他覚的にも筋力の低下がありました.

神経学的な解剖 (図2)：もっとも高次のレベルにあ るのが大脳です。大脳の下に脳幹, 小脳, 脊髄があ り, 脊髄から末梢神経が出ています。このうち運動神 経は, 筋肉に作用するために神経筋接合部から筋細胞 に達しています。どのような疾患を考えて筋力低下の 鑑別をすればよいかは，まずこの神経解剖からみて， 両下肢の筋力低下を来す疾患を挙げてください.

B：まず両下肢脱力ということから末梢神経というょ り脊髄から考えます。

下肢に症状があって上肢にないということは, 解剖 学的に脊髄（spinal cord）が冒されているのではない かということですね.

A : 部位としては末梢神経も.

末梢神経には運動と感覚という 2 種類の線維を含み ます．末梢神経は下肢で長いので下肢から症状が出や すいということから，上肢に症状がまだ出ていなくて も末梢神経レベルの障害も考えなくてはならないとい うことですね. 運動ニューロン疾患（motor neuron disease) と末梢神経疾患 (neuropathy) は区別すべ きで, 一般に感覚神経も一緒に障害されるものは末梢 神経疾患として区別します。ほかにはないですか？

A：やはり頭蓋内も.

まれですが, 両側に大脳半球が障害された場合には 両下肢に症状が来ることがあります。硬膜外血腫や髄 膜腫のように.ほかには?

$\mathrm{B}$ : 筋肉.

筋肉そのものの病気も重要ですね.ほかには?

$\mathrm{A}$ : 神経と筋肉の接合部.

神経筋接合部（neuromuscular junction : NMJ) も 重要ですね.ほかには?

$B$ : 脳幹部.

脳幹部も部位診断の 1 つとして入れておきましょ う. 以上より, 筋肉, $\mathrm{NMJ}$, 未梢神経または運動 ニューロン, 脊髄, 脳幹, 大脳などの部位診断を考え ます (図 2).

\section{Check Point :}

神経学的な鑑別診断を進めるうえで重要なことは (1)病変部位 (anatomy) を考える

(2)発症 (Onset), 時間的経過, 随伴症状などで病理

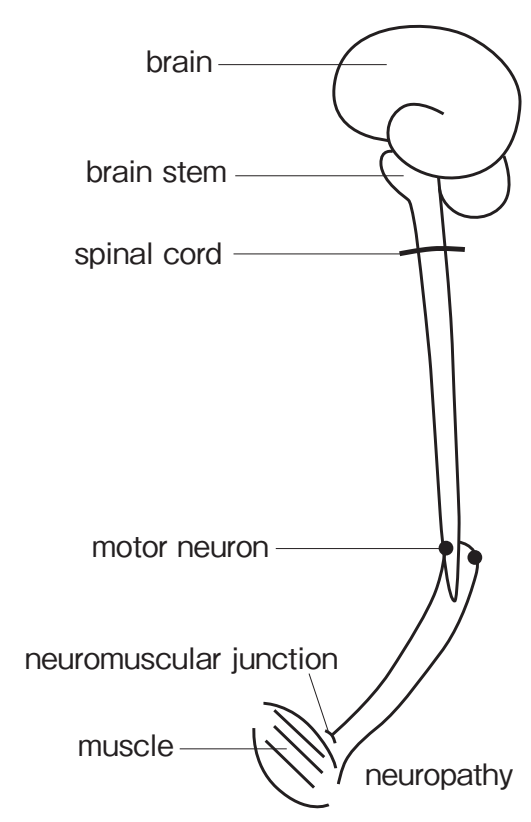

図 2 筋力低下の神経解剖の鑑別診断

\section{学的機序 (pathology) を考える}

たとえば, 代表的な病理学的機序として, 血管性病 変 vascular event の発症パターンは?

B : 突然発症です.

突然発症（Sudden Onset）ですね. 腫瘍性（Neoplastic) では?

B : 緩徐進行型です.

緩徐進行 (Slowly progressive) ですね. 感染症 Infectious Disease などの炎症性では, 比較的急性 acute なことが多いですね（例外：結核，真菌性な ど)。変性性 (Degenerative Disease) は慢性 (chronic) が多いです。その他, 先天性 (congenital), 自己免 疫性 (autoimmune), 外傷性 (traumatic), 内分泌性 (endocrine) などそれぞれの一般的な発症パターンを 理解しておくと役に立ちますね.

\section{Check Point : Anatomy と Pathology の両方の 視点 (行列) で考える (表 1).}

それでは現病歴を見てみましょう。（表 2)

12 月 25 日というのは, 受診 5,6 日前のことです. 階段を上るのがつらいというのは筋力低下があること を意味しています。もう少し所見が必要と思います が, まず anatomy からいきましょうか? どのカテゴ リーが考えやすいですか?

B：筋肉と思います。立てなくなったということで.

A : 筋肉に近い neuromuscular junction.

これだけの限られた情報では, neuropathy, motor neuron disease, そして spinal cord, このいずれも可 
表 1 Anatomy と Pathology の両方の視点（行列）

\begin{tabular}{|l|l|}
\hline \multicolumn{1}{|c|}{ (Anatomy) } & \multicolumn{1}{|c|}{ (Pathology) } \\
\hline Muscle & Vascular \\
NMJ & Infectious \\
Motor neuron & Neoplastic \\
Peripheral nerves (periph- & Degenerative \\
eral neuropathy) & latrogenic \\
Spinal cord & Congenital \\
Brain stem & Autoimmune \\
Brain & Traumatic \\
& Endocrine \\
& Psychiatric \\
\hline
\end{tabular}

\section{表 2 現病歴}

12 月 25 日の朝から両側の大腿の違和感（寝違えたよ うな感じ）を自覚したが歩行はできていた.

26 日に階段を昇るのがつらくなったが，自転車にはな んとか乗れていた.

27 日にはしゃがんでから立てなくなり，室内を這って 移動していた.

力を入れたときに大腿の前面，後面の筋肉痛があるた め湿布を貼って様子をみていた.

29 日に実家に帰り，親にも受診を勧められ救急要請, 来院した

上気道炎症状や消化器症状などの先行感染はなし. 学生で一人暮らし.

能性を否定できないと思います.

次は身体所見です。（表 3）

この中で異常と思われる所見は何でしょうか？

A : heart rate が 146 . 呼吸数も 24 と速い.

Heart rateの正常範囲は 60〜90 と言われていま す。かなりの頻脈です。呼吸数も成人は, 正常は 10 〜 18 回ですので速い.この 2 つはプロブレムリスト として残します。

次に神経学的所見をみてみましょう。（表 4）この 神経所見を説明できるような場所を, neuroanatomy から考えていきます。

A : 末梢の障害と考えて, spinal cord で両側性に来 ているのではないでしょうか?

spinal cordの障害で所見があわないのがありま

\section{表 3 身体所見}

119/90 mmHg, HR146 bpm, BT36. $9^{\circ} \mathrm{C}, \mathrm{RR} 24 / \mathrm{min}$ 【既往歴】喘息

眼瞼結膜貧血なし，眼球結膜黄染なし，頸部リンパ節 触知せず

心音：整・心雑音なし，肺音：清

腹部：平坦軟グル音正常, 肝脾を触知しない

下腿浮腫なし両足背動脈触知良好

\section{表 4 入院時神経学的所見}

1. 意識：清明

2. 脳神経系 : 正常

3. 運動系：

MMT

neck flex. $5 \quad$ neck ext. 5

deltoid $\quad 5 / 5 \quad$ iliopsoas $\quad 5 / 5$

biceps $5 / 5 \quad$ quadriceps $3+/ 3+$

triceps $\quad 5 / 5 \quad$ hamstrings $4-/ 4-$

wrist ext. $5 / 5 \quad$ tibialis ant $3+/ 3+$

wrist flex. 5/5 gastrocnemius $4-/ 4-$

I と II 〜 Vの対立 $5 / 5$

筋萎縮なし筋把握痛なし筋トーヌス異常なし筋 線維束攣縮なし

不随意運動なし SLR-/-

4. 深部反射 $: H(-/-) T(-/-) W(-/-) B(-/$ 一) C (-/-) 足クローヌス $(-/$ - ) 膝クローヌ ス $(-/-)$

5. 感覚 : 触覚・温冷覚・痛覚 : 正常 6. 一人で起 立不可

す。それは腱反射（DTR）です. Spinal Cordの障害 であれば，上位運動ニューロン障害ですから，DTR は立進します。もう一つ, spinal cord は小さな面積 の断面をもっています. Spinal cordが障害されると 一般的に sensory も同時に障害されます。この方では sensoryは intact です。そうすると spinal cord ではな さそうです。両下肢の筋力低下と聞くと, spinal cord disease と速断しますが, DTRの消失, そして sensory が intactであるということは, spinal cordの障害で は説明が難しくなりますね.

B：腱反射が低下しているということを考えると， motor neuron disease $と$ neuromuscular junction, そ して muscleも考えられます。

Neuropathyは?

B : Neuropathy であれば sensory が intactであるの が合いません.

peripheral neuropathy には, 運動神経優位の疾患, 感覚神経優位の疾患があります。感覚神経優位の疾患 は結構多いですが，その逆もあります。また，病気の 進行の度合いにもよります。たとえば病気が初期であ ればどちらかのみが障害されているような症状を呈し ます。ですからこの症例では neuropathy はまだ鑑別 に残しておいた方がよいでしょうね.

Spinal cord, motor neuron 疾患そして peripheral neuropathy, neuromuscular junction そして muscle disease, このような一連の anatomy の部位診断が 考えられます。この anatomy に今度は pathologyを 加味して，この患者の病歴と身体所見からどういう病 
気が考えられるか挙げてください. 表 1 のリストから 疾患を挙げていきましょう.

まず spinal cord はどうですか?

B : 春髄炎?

Myelitis． 横断性脊髄炎がありますね.

B：現病歴をみると比較的急性です.

表 1 から脊髄炎以外の acute なものは? vascular event はどうですか?

B : 前脊髄動脈症候群 (anterior spinal cord artery syndrome）。 あと acuteではないですが脊髄腫瘍.

脊髄原発の腫瘍もありますが, まれで, 転移性の脊 椎の腫瘍が脊髄を圧迫することが頻度としては高いで すね (tumor/compression).

B : 外傷.

感覚障害がないのと, 腱反射が消失しているので, spinal cord の可能性は下がります.

では次に motor neuron 疾患に行きましょう。

\section{A：具体的な病名はわかりません.}

motor neuron disease は原因不明の変性疾患が多 いです。もっとも有名なのはなんですか？イギリス・ ケンブリッジ大学に世界的宇宙物理学者がいますね.

B : ギランバレー症候群 ?

ギランバレー症候群は motor neuron disease では ありませんよ，上位と下位運動ニューロンの両方が障 害されるのは.

A : ALS (筋萎縮性側索硬化症)。その博士はホーキ ングです.

そうです．ALSは上位と下位の両方が障害されま すから，下肢に関しては腱反射が充進します。感覚障 害がないというのは, motor neuron disease の重要な 特徵です。この症例には合いません. しかも motor neuron disease のほとんどは chronic な経過をたどり ます．ALS 以外に下位だけ運動 neuron が障害される ものがあります. Lower motor neuron disease です.

とくに有名なのはあるウイルスでおこるものがありま

す。今はワクチンの普及のおかげでほとんど発症はあ

りませんが.

B : ポリオ?

はい，ポリオですね．以上は解剖学的には説明でき ますが，ポリオは現在考えにくい，今回は感覚障害も あるので, motor neuron disease は鑑別から下がりま す.

では neuromuscular junction にいきましょうか? 両下肢の筋力低下を来すような疾患は?

C : MG (重症筋無力症; Myasthenia Gravis).
MG は通常, 眼球運動障害とか眼瞼下垂など, 外眼 筋の麻痺を来すか, 眼瞼を支配している筋の筋力低下 を来す。四肢より頭部に症状が出やすい.そのほか neuromuscular junction が障害される疾患は?

A : Lambert Eaton 症候群.

そうですね. これと MGの二つが, 代表的な neuromuscular junction disease です. Lambert Eaton 症 候群は好発年齢が高齢者で, 顔面や上肢の筋力低下が 特徵的です。感覚障害はありません. したがって neuromuscular junction disease も鑑別から下がりま す.

次は muscle disease です.

B : 多発性筋炎 (polymyositis).

表 1 のカゴリーでは, autoimmune です. polymyositis の発症年齢は二峰性パターンで小児にも見ら れ高齢者にも見られます。この患者には皮膚所見はあ りませんが多発性筋炎の可能性は残しておきましょ う. 筋肉痛, 筋力低下が下肢から来ることもありま す. 他は?

B : PMR（リウマチ性多発筋痛症 ; Polymyalgia rheumatica).

これは autoimmune の中に入れてもいいですが, ただ好発年齢が高齢者ですね. 頚, 肩，上肢の症状が 多い. PMR はリウマチ関連疾患で多彩な症状を呈し ます．関節痛，朝のこわばりで来ることがありますか ら鑑別に残すべきでしょうが, 多発性筋炎と比べる と，好発年齢が合わないことと筋肉痛がメインで，筋 力は原則低下しない. そして血清 $\mathrm{CPK}$ も上がりませ 几. 多発性筋炎は通常 CPK は上がります。ほかの muscle disease はありませんか? 筋肉に二次的に来る ものでもいいですよ.

C : 周期性四肢麻盘 (Periodic Paralysis : PP)

日本人の男性で Periodic Paralysis を見たら，まず 甲状腺機能立進症（Basedow 氏病）を考えます。こ の患者はそのような既往はありません.

C : HR146 が高いので...

電解質異常による障害が筋肉に影響を与える，筋肉 の病気というょりは内分泌疾患で K が低下するのが 主なメカニズムです。筋力低下を来たし, 深部腱反射 を来すほかの疾患はありませんか？

$\mathrm{Ca}$ 代謝異常で筋力が低下するのは Ca が高いとき です，逆に低 Ca 血症は，筋力低下というょりは，筋 肉のスパスムをおこすことが多い. 筋力低下というこ とを考えると, 代表的なのは低 $\mathrm{K}$ 血症と高 $\mathrm{Ca}$ 血症で す。あと $\mathrm{Mg}$ は Ca と同様の症状を出すことがありま 
す. $\mathrm{Mg}$ と $\mathrm{Ca}$ は症状が似ています.

今までいろいろ議論しましたが, muscle disease で 感覚障害がおこるというのは説明困難です。でも可能 性として muscle disease の多発性筋炎と電解質異常 は鑑別に残しておきましょう。

最後に neuropathy, なかでも motor dominant polyneuropathy にはどのような疾患がありますか？表 1 のカテゴリーから挙げてください.

A : amyloidosis.

一般的には sensory と motor の両方やられます。 amyloidosis は表 1 に追加で metabolic に入れましょ j.

B : Guillain-Barré syndrome (GBS).

表 1 の infection に inflammatoryも含めましょう。 GBS は motor dominantでくることが多い. 比較的 acute に来ます。

B : ビタミン B12 欠乏?

ただビタミン 12 のときは, 通常 neuropathyのみ ではなく spinal cordも障害されることが多い. 亜急 性連合性脊髄変性症です。

B : 葉酸?

葉酸で来るのは, 貧血, 先天異常です. 妊婦が葉酸 欠乏, 葉酸代謝に拮抗するような物質や薬剤を飲んだ ときに葉酸欠乏で二分脊椎の赤ちゃんが生まれること があります。後天的な葉酸欠乏では，神経がやられる というよりは, 葉酸補充のみではビタミン B 12 欠乏 で来ます。ビタミン B 群ではほかに?

B : ビタミン $\mathrm{B} 1$.

ビタミン B1 が久そして，神経所見を来すのは？

B : 脚気 (beriberi).

昔は脚気が多かったですね. ビタミン B1 をあまり 摂取していませんでした，ビタミン B1 の欠乏が脚気 の原因であるということを発見した人は誰ですか？日 本人高木兼寛が疫学的に証明しました. 最初は細菌説 が提唱され，森鴎外は感染症だと考えました，高木は 軍の食生活をみてビタミン欠そ症ではないかと考えた のです．脚気患者は精製された米のご飯を食べてお り, 精製されていないご飯を食べさせたところ脚気発 症が減少した。ところで beriberi は最近どうでしょ うか?

B : アルコール中毒に多いです.

そうですね。まったく食事を食べないでお酒ばかり を飲む人に脚気はハイリスクです。末梢神経にくると 脚気ですが，脳に来ると？

B : Wernicke 脳症.
はい，それとコルサコフ症候群ですね. 酒飲みは脚 気，コルサコフ症候群のリスクも高い。他には？

B : 糖尿病 ?

糖尿病も motor dominant で来ることもありますか ら重要です。ただこの患者はそのような病歴はありま せん.

以上を挙げていくと, neuropathy と muscle の疾 患に絞られてきました。

ではいつものように, 各グループで, この中で一番 可能性が高いかを挙げてください.

A : 先行感染がなかったので, ギランバレーは考えに くいです.

下肢から来るというのはギランバレーによく見られ ますが, あきらかな先行感染がない. GBS, beriberi, polymyositis そして電解質異常の 4 つから選ん でください

A : polymyositis だと思います. その場合，検査は何を行いますか？

A : 抗体検査です.

抗核抗体 (ANA) と CPK ですね. 必要に応じて筋 電図を行います。確定診断のためにはなんですか?

A : muscle biopsy です.

そうです。ただ polymyositis にしてはこの患者は 腱反射が消失し感覚障害もあり, 筋肉痛が無い点が気 になります。

B：一番は脚気だと思います。 beriberiになるリスクはどういう食生活ですか？

B : カップラーメンしか食べないとか.

最近のカップラーメンにはビタミン B1 が含まれて いるのもありますが, 食生活を切り詰める一人暮らし の男子学生はハイリスクグループです.

B : HR が早いのは?

beriberi は hyperdynamic state になります。ひど くなるとWet beriberi といって心不全を来します. Wetは体液が貯留しているということです。肺水 腫，下肢のむくみを来します。そうすると心拍出量が 増えていても心不全を来します。 beriberi 疑いに関しては何を検査しますか？

B : ビタミン B1 を測定します. ビタミン B1 の測定結果が返ってくるまでにするこ とはありませんか？

B : ビタミン B1 を投与して改善するかどうかを見る. その通りです。そういうのを治療的診断といいま す.

C : 栄養状態はどうでしょうか？ 
やせ形です。ただし甲状腺腫とかはない. 眼球突出 などの所見もありません，発汗，振戦もなし．

C : Periodic Paralysis も考えます.

PP に関しては電解質異常をチェックし, 甲状腺機 能を検查します。

そのほか GBS は鑑別診断に挙がりませんでした が，疑い例では何をすればいいでしょうか，参考所見 になる検査がありますね.

A : 髄液検查.

はい，髄液検査で蛋白細胞乘離を見ます。

では検查所見を見ます（表 5).TSH が正常ですの で, 甲状腺機能立進症は否定されます. 電解質異常 は?

B : K, Ca は正常です.

それでは鑑別は beriberi, GBS, polymyositisの 3 つに絞ってよろしいですか.

その後の髄液検查所見で蛋白髄液が上がっていませ ん. そこで GBSは考えにくい. CPK は正常範囲で す.したがって polymyositis も可能性が下がりま す.ということで, beriberi の可能性はどうでしょう か.

では治療経過です（表6)。退院前の神経学的所見 も表 7に示します．最終的な検查結果として，血中の ビタミン B1 が低下していました.

確定診断：ビタミンB 1 の投与とリハビリで MMT （徒手筋力テスト）が改善したため「脚気」と診断. 2 週間後に返ってきた血液検查でもビタミン B 1 が 低下していたため確定診断となった.

われわれは入院後の回診で, 本人からカップラーメ ンしか食べていないことを聞き出，これは脚気の可能 性は否定できないと考えました，患者が愛食していた カップラーメンの製品も調ベてビタミン B1 が入って

表 5 髄液検査 $(1 / 4)$

\begin{tabular}{|c|c|c|c|}
\hline 検査項目 & 結果 & 単位 & 正常値 \\
\hline 外観 & 無色透明 & - & - \\
\hline 細胞数 & 5 & $/ \mathrm{mm} 3$ & $<6 / \mathrm{mm} 3$ \\
\hline 単核球 & 4 & $\%$ & - \\
\hline 多核球 & 1 & $\%$ & - \\
\hline 比重 & 1.005 & 一 & - \\
\hline 蛋白定量（髄液） & 36 & $\mathrm{mg} / \mathrm{dl}$ & $15-45 \mathrm{mg} / \mathrm{dl}$ \\
\hline 糖定量（髄液） & 58 & $\mathrm{mg} / \mathrm{dl}$ & $\begin{array}{l}\text { 血 糖 值 の } 1 / 3 \\
\text { 以上 }\end{array}$ \\
\hline 血糖（血漿） & 90 & $\mathrm{mg} / \mathrm{dl}$ & $60 \sim 110 \mathrm{mg} / \mathrm{dl}$ \\
\hline
\end{tabular}

\section{表 6 治療経過}

12/25 頃より大腿の筋力低下の進行を認め歩行不可と なった 23 歳男性. 筋の把握痛や萎縮なく, CK 上昇も 認めないことから myopathy は否定的であり, 筋力低 下，腱反射低下を認め distal neuropathy と考えた。 病歴上, 明らかな先行感染はなく, 障害部位の上行も なかったが, L/D 上, 肝機能障害あり, ギランバレー 症候群も鑑別に挙げ，経過観察必要と考えられたた め, 入院経過観察とした.

1/4 の冎道液検査では異常所見はみられなかった.

病歴上, 秋頃カップラーメンしか食べてなかった時期 が 2 週間以上あり VitB1 欠乏症も考えられ 1/4 VitB1 提 出し同日よりビタメジン注射十アリナミン内服を開始 した.

その後リハビリも併用し，徐々に下肢筋力も改善がみ られた.

1/20には下記のようにMMT 回復し, 松葉杖歩行も可 能になったため $1 / 22$ 退院, 以後アリナミン内服継続と した.

表 7 退院前 (1/20) 神経学所見

\begin{tabular}{lrlr}
\hline neck flex. & 5 & neck ext. & 5 \\
deltoid & $5 / 5$ & iliopsoas & $5 / 5$ \\
biceps & $5 / 5$ & quadriceps & $4+/ 4+$ \\
triceps & $5 / 5$ & hamstrings & $4+/ 4+$ \\
wrist ext. & $5 / 5$ & tibialis ant & $4+/ 4+$ \\
wrist flex. & $5 / 5$ & gastrocnemius & $4+/ 4+$ \\
深部腱反射 & & \\
上肢低下なし, PTR-/ー, ATRー/ー（増強法にても同 \\
様）
\end{tabular}

いないことも調べました． 即日からビタミン B1 投与 （初期数日 $300 \mathrm{mg}$, その後 $100 \mathrm{mg}$ ）を連日投与し, リハビリも徐々に進めて行って歩行できる時点になっ て退院となりました．B1 投与のあと HR も落ち着い てきました

この患者は筋力低下という主訴で来院しました。そ の鑑別を考えるうえで, neuroanatomyでどの障害部 位かを考え，さらに病態生理を考えました。この両方 を考えながら鑑別を挙げていき，この患者の病歴をも う一度樑く聞き直すことによって, 診断に至りまし た.

\section{Check Point : 脚気の診断は食生活や飲酒歴を聞く ことが重要}

C : ビ夕ミン B1 が不足するとアシドーシスがくるの でしょうか

それは重要な質問です. beriberi はビタミン B1 欠 そですが，ビタミン B1 はそもそもブドウ糖の代謝に 必須の補醭素です。これが久乏すると，TCA サイク ルの入口でブロックされて lactate（乳酸）が増えま 
す. lactate が増えるとアニオンギャップが開大する タイプの代謝性アシドーシスとなります。この患者で は $\mathrm{pH} 7.397$ でしたが, $\mathrm{HCO}_{3}$ は 21 と低下し, $\mathrm{PCO}_{2}$ も下がっており呼吸性の代償がありました。呼吸数が 速いというのは実は鍵だったのです。呼吸数を速くし て代償性呼吸性アルカローシスにして primary の代 謝性アシドーシスの効果を相殺しょうとしている。 こ こでは乳酸アシドーシスはあったのです。ビタミン B1 を投与すると数時間以内にアシドーシスは軽快す るという特徵があります。

医原性のビタミン $\mathrm{B} 1$ 欠乏が以前はありました IVH で高カロリー輸液を行う患者にビタミン B1 を十 分入れられていなかったために重篤な代謝性アシドー シスが報告されました。

いまは IVH の輸液内には必ずビタミン B1 を入れ るようになっていると思います.

ビタミン B1 が不足する病態では，アルコール依存 症とカップラーメンばかり食べるのに加え, 最近注目 されているのは利尿剤の長期投与です，水溶性ビ夕ミ ンですからすぐに尿中に排出されます。しかもループ 利尿剂は強力な利尿剂ですので，ビタミン B1 はどん どん尿中に失われていき, 体内のビタミン B1 も欠乏 していきます。とくに心不全患者にループ利尿郕が投 与されてビタミン B1 が欠そすると心臟によくありま せん．心臟の悪い人にループ利尿剂を投与していると ビタミン B1 が欠そし，これが心不全増悪のトリガー

\section{表 8 病態生理学プロセスの代表的な分類「VINDICATE」}

\author{
Vascular：血管 \\ Infection : 感染症 \\ Neoplastic：腫瘍性疾患 \\ Degenerative：変性疾患 \\ latrogenic：医原性疾患 \\ Congenital : 先天疾患 \\ Autoimmune：自己免疫性疾患 \\ Traumatic：外傷性疾患 \\ Endocrine\&Metabolic： 内分泌代謝疾患
}

となっているのではないかといわれています。ですか らループ利尿剤投与の患者にはビタミン B1 を補充し たほうがよいのです。

以上，今回は筋力低下の鑑別診断を見てきました。 まとめますと，

Check Point : 筋力低下, 神経学的な症状において は, 神経解剖学的なカテゴリーに分けて考える.「筋 肉, 神経筋接合部, 末梢神経, 運動ニューロン, 脊 㵦, 脳幹部, 脳」

Check Point : 解剖学的なカテゴリーの中で, どの ような病態が起こっているかのプロセスを考える

病態生理学的プロセスの代表的な分類である「VINDICATE」を表 8 に示します.

これで総合カンファレンスを終了します.

「総合カンファレンス」の既掲載一覧

第 1 回：札幌医科大学地域医療総合医学講座 34 巻 1 号, 2011 年

第 2 回：原因不明の発熱を訴える 68 歳男性 名古屋第二赤十字病院総合内科 34 巻 2 号

第 3 回：臨床推論の症例検討会 水戸協同病院 34 巻 3 号

第 4 回：24歳男性の不明熱 天理よろづ相談所病院総合内科 34 巻 4 号

第 5 回：めまい 広島大学総合内科 35 巻 1 号, 2012 年

第 6 回：虫垂炎 国立病院機構名古屋医療センター総合内科 35 巻 2 号

第 7 回：診療所カンファレンス 大福診療所 35 巻 3 号

第 8 回：菊池病 自治医大グランドカンファレンス 35 巻 4 号

第 9 回：NOMI 東邦大学総合診療・急病センターカンファレンス 36 巻 1 号, 2013 年

第 10 回：レジオネラ肺炎 北海道家庭医療学センターグラウンドカンファレンス 36 巻 2 号

第 11 回：高齢者糖尿病 国立病院機構 東近江総合医療センター総合内科 36 巻 3 号

第 12 回：筋力低下 筑波大学水戸地域医療教育センター・水戸協同病院 36 巻 4 号 